\title{
Analysis of Local Economic Potential and Economic Competitiveness in Surabaya City
}

\author{
Yusuf Hariyoko ${ }^{1}$, Anggraeny Puspaningtyas ${ }^{2}$ \\ ${ }^{1}$ Faculty of Social and Political Science, University of 17 Agustus 1945 Surabaya (email: yusufhari@untag- \\ sby.ac.id), ${ }^{2}$ Faculty of Social and Political Science, University of 17 Agustus 1945 Surabaya \\ (email: anggraenypuspa@untag-sby.ac.id)
}

\begin{abstract}
Law Number 23 of 2014 concerning Regional Government clause 29 verse 5 explains that "The strategy for accelerating regional development as referred to in clause (4) covers the priority of development and management of natural resources in the sea, acceleration of economic development, socio-cultural development, humans development resource, development of customary law related to sea management, and community participation in development. Economic growth is one indicator of economic success in Indonesia, but in the course of economic growth there are several economic problems. The main economic problems according to Adisasmita (2005: 201) are (i) consumption; (ii) production; (iii) distribution; and (iv) growth. Economic growth of Indonesia depends on the production of goods and services in the real sectors produced. Surabaya is the second largest city after Jakarta in Indonesia, it is important to explore local economic potential and regional economic competitiveness to encourage the acceleration of the regional economy. The potential of local economic may not be competitive with all districts in the East Java Economic Province. Location Quotient and Shift Share analysis can be a basic calculation method for determining the acceleration of economic development in a region. Based on the Location Quotient analysis, it can be seen that the three main potentials of the local economy are the company's service sector $(\mathrm{LQ}=3.056)$; and the sector of providing accommodation and food drink ( $L Q=2,818)$; financial and insurance sector ( $L Q=1,937)$. While the three main sectors that are competitive are large and retail trade $(S S=11,172.2)$; car and motorcycle repair sector (SS = 8,113,6); and the sector of providing accommodation and food drink and processing industries (SS $=7,616,7)$. It can be concluded that the leading sectors and competitive sectors can be used as the basis for accelerating the economic development of Surabaya City.
\end{abstract}

\section{Keywords:}

local economy; economy potential; competitiveness

\section{Introduction}

The national development planning system in Indonesia as stipulated in Law number 25 of 2004 concerns about the national development planning system divides the scope of planning in a systematic and integrated manner. Integrated meaning can be 
interpreted as alignment of development planning between spaces (time) and between levels of government. According to Tjokroamidjojo, planning is considered as a way to achieve goals well, one of the benefits of planning is "by planning an estimate (forecasting) is carried out on things during the implementation period to be passed. Estimates are carried out regarding the potential and development prospects, also recognize the risks that may be faced. Planning organized so that uncertainty can be limited as little as possible "(Sudriamunawar, 2012: 67). The development of the implementation of development today, the target of planning is not only planning to overcome economic problems but more associated with a healthy overall economic process. The state's development process is not only in the planned economic field but also in the social sector and must be planned in a comprehensive and balanced manner.

Economic growth is a very important indicator to know and evaluate the results of development carried out by a country, especially in the economic field. Economic development in Indonesia has been pursued and has been going on since independence with various economic development strategies, policies and programs to realize prosperity for the entire community. During the more than seven decades of Indonesian independence, prosperity was only felt by a small proportion of the population, while poverty, backwardness and helplessness were still felt by most of the population who should have the right to prosperity and be treated fairly. In accordance with the contents of the 1945 Constitution clause 33 verse 4 states that "The national economy is organized based on economic democracy with the principle of togetherness, efficiency, justice, sustainability, environmental insight, independence and by maintaining a balance of progress and unity of the national economy".

Indonesia's economic recovery occurred in 2000-2004 with an average growth of $4.6 \%$ per year. The acceleration of excellent economic growth is ahead of 2011 due to increased household consumption (amid strong per capita GDP and consumer purchasing power) and the explosion in commodity prices. But in 2011-2015, an economic slowdown emerged that caused concern. The World Bank stated that the growth of Indonesia's economic growth was due to still having consumer power that drove the economy and significantly triggered the growth of domestic and foreign investment. At the end of 2017, the World Bank said that 52 million Indonesians are into the middle class category which has a large potential to 
contribute to the growth of the economy. Indonesia's statistic, growth of Gross Domestic Product ( GDP ) in 2007-2018 can be seen in table 1.

Table 1.

Growth of Gross Domestic Product (GDP) in 2007-2018

\begin{tabular}{|c|l|c|c|c|c|c|c|c|c|c|}
\hline No & Information & $\mathbf{2 0 1 0}$ & $\mathbf{2 0 1 1}$ & $\mathbf{2 0 1 2}$ & $\mathbf{2 0 1 3}$ & $\mathbf{2 0 1 4}$ & $\mathbf{2 0 1 5}$ & $\mathbf{2 0 1 6}$ & $\mathbf{2 0 1 7}$ & $\mathbf{2 0 1 8}$ \\
\hline 1 & $\begin{array}{l}\text { GDP (In Billion } \\
\text { USD) }\end{array}$ & 755,0 & 893,0 & 918,0 & 915,0 & 891,0 & 861,0 & 933,0 & & \\
\hline 2 & $\begin{array}{l}\text { GDP (\% annual } \\
\text { change) }\end{array}$ & 6,2 & 6,2 & 6,0 & 5,6 & 5,0 & 4,9 & 5,0 & 5,1 & 5,17 \\
\hline & $\begin{array}{l}\text { GDP Per Capita (In } \\
\text { USD) }\end{array}$ & 3,167 & 3,688 & 3,741 & 3,528 & 3,442 & 3,329 & 3,603 & & \\
\hline
\end{tabular}

Source: World Bank

GDP is basically the amount of added value produced by all business units in a particular country, or is the amount of added value produced by all business units in a particular country, or is the amount of the value of goods and final services produced by all economic units. One indicator of economic growth is Gross Domestic Product (GDP) both on the basis of validity and constant prices. The following is an overview of GDP from 20072016 in billion USD.

Figure 1.

Gross Domestic Product in 2007-2016

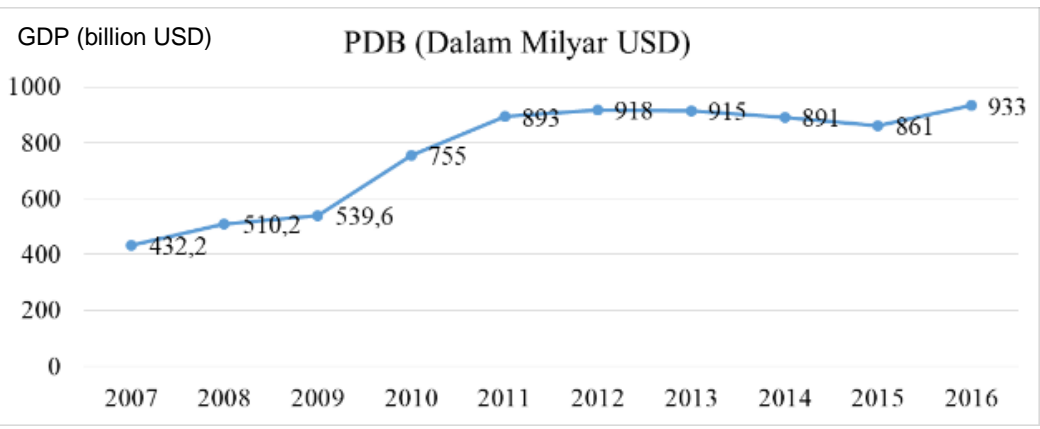

Source: World bank

The economic growth of a region can be seen through various impacts from several indicators that support economic activity. Some indicators of economic development are the Human Development Index (HDI), the percentage of poor families, the open unemployment rate and the inflation rate. Reflect on the vision of the East Java Long Term Development Plan (RPJPD) 2005-2025, namely the realization of East Java as the "Leading Agribusiness Center, Global Competitiveness, and Sustainability", through five stages of periodization. The 2014-2019 period is the third phase of mid-term development based on the 
implementation, achievement, and sustainability in the first and second stages of development aimed at emphasizing on the achievement of competitiveness in economic competitive based on the superiority of quality natural resources and human resources, as well as scientific and technological capabilities which continues to increase. Attractive economic dynamics in the previous stage was strengthened by expanding the reach of the working network of economic activities that were not national scale but also international.

During the last five years, Surabaya's economy has been able to grow stably in the range of $6 \%$ up to $7 \%$. The economic growth rate is higher compared to the average economic growth of East Java and national. Although Surabaya's economic growth experienced a slowdown since 2014-2015 which in around 6\% due to the factor of global economic instability. The following is the problem of the quality of economic growth according to the Surabaya City Medium Term Development Plan (RPJMD) in 2016-2021:

1. Economic growth has not been followed by an increase in employment, indicated by high unemployment;

2. Economic growth has not stimulated the occurrence of equal distribution of income between regions as indicated by the index of regional inequality which is still high;

3. The highest economic growth in Surabaya City is supported by the category of business fields, non-tradables (sectors that do not absorb a lot of labors) and the elasticity of economic growth in absorbing workers is getting lower;

4. The economic growth of Surabaya City still has not been able to contribute to poverty alleviation problems.

By referring to Surabaya City, Gross Regional Domestic Product (GRDP) in 2013-2017, it can be seen the superior sectors and non-superior sectors and also the highly competitive sector and the low competitive sector. In accordance with Ratnasari's opinion in her journal, "with a combination of economic base sector approach and empirical experience, it is hoped that integration between the base sector and the non-base sector can be realized as an important element in driving economic growth in the future" (Ratnasari, 2014: 21). The basis of economic development planning can be used as a basis for the model of economic development plan in Surabaya city. 


\section{Methods}

The data analysis technique in this research in a quantitative approach uses analysis of data location quotient (LQ) and shift share (SS). The first thing the researchers did was analyze the potential of the local economy by using LQ analysis techniques. After the LQ results are known, then the shift share (SS) analysis is carried out to find out in detail the economic growth of Surabaya Regency. After LQ and SS analysis are done, the conclusions can be drawn.

Location quotient (LQ) is intended to find an overview of the capabilities of the development sectors in a region in supporting the development process in the region. According to Hafizrianda and Daryanto, "LQ is a simple indicator that can show the strength or size of the role of a sector in an area compared to the other or the reference area" (Hafizrianda and Daryanto, 2010: 20). "In LQ techniques various variables (factors) can be used as indicators of regional growth, for example employment (labor) and gross regional domestic product (GRDP) of an area" (Adisasmita, 2008: 21). The following is a formula for calculating the location quotient (LQ):

$$
\text { Formula } \rightarrow \mathrm{LQ}=\frac{x_{i r} / x_{r}}{x_{i n} / x_{n}}
$$

Formula description:

$\mathrm{LQ}=$ Location Quotient

Xir = "i" sector GRDP value at the lower regional level

$\mathrm{Xr}=$ Total GRDP at the lower regional level

Xin $=$ "i" sector GRDP value at the upper regional level

$\mathrm{X} n=$ Total GRDP at the upper level

Shift share analysis describes the performance and productivity of the sectors in the economy of a region by comparing it with the performance of sectors in one region above (provincial / national). This analysis compares the rate of growth of regional economic sectors with higher levels of economic growth. Using shift share analysis can be seen changing in economic structure during certain observation periods. To get the shift share results, it is necessary to calculate first, the three components of shift share, namely national share (NS), Industry-Mix and Competitive Position. The following is the formula for calculating the shift share and its components:

$$
\text { Formula } \rightarrow \mathrm{Dij}=\mathrm{Nij}+\mathrm{Mij}+\mathrm{Cij}
$$


To calculate shift share analysis, components are needed to calculate into one shift share unit. The calculation formula for shift share analysis components is as follows:

$$
\begin{aligned}
& \mathrm{Nij}=E \mathrm{Eij} *(\mathrm{Rn}-1) \\
& \mathrm{Mij}=\mathrm{Eij}^{*} \text { (Rin-Rn) } \\
& \mathrm{Cij}=\mathrm{Eij}^{*} \text { (Rij-Rin) }
\end{aligned}
$$

Formula description:

$\mathrm{Dij}=$ economic shift from sector $\mathrm{i}$ region $\mathrm{j}$ in a period of time (one year)

$\mathrm{Nij}=$ level of national development sector $\mathrm{i}$ area $\mathrm{j}$ (National Share)

Mij $=$ mixed industry sector $\mathrm{i}$ region $\mathrm{j}$ (Industrial Mix)

$\mathrm{Cij}=$ superiority competitive sector $\mathrm{i}$ region $\mathrm{j}$ (Competitive Position)

$\mathrm{Eij}=$ value of sector $\mathrm{i}$ region $\mathrm{j}$ in the initial year of analysis

$\mathrm{Rn}=$ total higher speed of regional development

Rin $=$ the level of development of the sector $\mathrm{i}$ in the higher level region

$\mathrm{Rij}=$ level of development of sector $\mathrm{i}$ in region $\mathrm{j}$

After the results of the LQ and SS analysis are known, a method is needed to draw analysis conclusions. The researcher used the overlay analysis method to draw conclusions. The overlay analysis method is the method used to determine the leading sector by combining the results of the shift share analysis method and location quotient (LQ). The purpose of this overlay analysis is to see a description of potential economic activities based on contribution criteria (analysis of location quotient) and growth criteria (shift share analysis). In this overlay analysis there will be four possibilities:

1. If growth $(+)$ and contribution $(+)$, then the sector is quite dominant so it must get priority in development;

2. If growth (+) and contribution (-), then the sector is undergoing development so that it needs attention to increase its contribution in determining GRDP;

3. If growth (-) and contribution (+), then the sector is experiencing a decline so it needs to be spurred on growth;

4. If growth (-) and contribution (-), then the sector is not potential so it is not feasible to be developed (Arsyad, 2010: 393). 


\section{Result and Discussion}

The basic problems for central and regional governments in Indonesia are poverty, inequality, unemployment, infrastructure and low quality of human resources. Many problems that occur can be overcome by encouraging economic growth as a move spirit with uses in exist economic potential. The economic potential that can be maximally utilized can improve other sectors so that it can have an impact on regional competitiveness. Mrs Hicks argues that "the problem of underdeveloped countries involves the development of sources that have not or have not been used, the use of this problem is well known, while the problems of developed countries are related to growth, because most of their sources are known and developed to a certain extent" (Mrs. Hicks in Jhingan, 2014: 4). Factors that can increase economic growth are natural resources, capital accumulation, government organizations, technological progress, division of labor and scale of production, social, cultural and political organizations.

The instrument that has the most impact on people's welfare is the development of the local economy as a move spirit of accelerated regional development. According to Blakely and Bradshaw (2002), "local economic development is the process by which local governments and community organizations are involved to encourage, stimulate, maintain business activities so as to create jobs". In line with Blakely and Bradshaw's opinion, the World Bank believes that "the goal of local economic development is to build regional economic capacity, improve the economic future and quality of life for all people" (Merauje, 2017: 44). The government, business / non-government sector and the society can work together to collaborate to create better conditions for creating employment and increasing competitiveness to promote sustainable economic growth.

One of the important objectives of planning in underdeveloped countries is to increase the pace of economic development (Jhingan, 2014: 519). While economic development planning means directing or regulating economic activities by increasing the rate of capital formation, increasing income, savings and investment, exports and imports as well as fiscal and monetary policies.

Practically, the planning approach can be done by means of a sectoral approach and regional approach. According to Taringan (2012: 33), "a sectoral approach with focuses on 
the sectors of activity in the region. This approach classifies economic activities based on the same sectors or considered similarity.

Development planning with a sectoral approach which all economic activities in the planning area are grouped into sectors that can be analyzed one by one of each sub-sector. Sector is a collection of activities or programs that have similarities in characteristics and objectives to make easy for calculations in achieving macro objectives. According to Taringan, "Every sector sees from its potential and opportunities, determines what can be improved and the location from the activities" (Taringan, 2012: 36). Each sector is analyzed again (break down) so that there are homogeneous groups. Each sub-sector can be broken down on the basis of commodities, for example for the food sub-sector can be specified on the commodities of rice, vegetables, fruits and so on. These sectors have different characteristics and have different driving forces depend on the potential of the region.

Gross Regional Domestic Product (GRDP) is the total amount of added value from goods and services made by various production units in a region in a particular period (annual). Added value is the output subtracted result between input (Widodo, 2006:78). With production approach, the national product or the gross domestic product is obtained by adding the market value of all goods and services that are made by various sectors in economy. GRDP is the all of the end demand components consist of: 1) household and non governmental organizations consumption expense, 2) government consumption, 3) gross domestic constant capital formation, 4) stock changes, and 5) net export, (export subtracted by import) (Widodo, 2006:79). Expenditure approach is the approach of national income or Gross Regional Domestic Product obtained by adding the market value of all the end demand based on the output produced in an economy, measured by the valid market price. Calculating added value of economy group by added value allocating into each economic activity group in regional level as an allocator is used mostly depending on or closely related to the productivity of the aforementioned economic activities through GRDP according to the current price and constant price. GRDP presentation is done in two ways, which are the followings:

1. GRDP Based on Constant Price

GRDP Based on Constant Price is obtained based on constant price, the comparator is constant and the nominal is smaller than the current price. 
2. GRDP Based on Current Price

GRDP Based on Current Price is obtained based on the current price in the analysis year and it is not affected by inflationary or price.

Sectors in GRDP are 1) agriculture, forestry and fisheries; 2) mining and excavation; 3) processing industry; 4) procurement of electricity and gas; 5) water supply, waste and recycling management; 6) construction; 7) large trade and retail, car and motorcycle repair; 8) transportation and warehousing; 9) provision of accommodation and food drinks; 10) information and communication; 11) financial and communication; 12) real estate; 13) company services; 14) government administration, defence and compulsory social security; 15) education services; 16) health services and social security; and 17) other services.

The basis of the data for data analysis is the component of Gross Regional Domestic Product (GRDP) based on current prices, both at the East Java Province and Surabaya City levels in 2013-2017. Data GRDP ADHB in East Java Province in 2013-2017 can be seen on the second table.

Table 2.

GRDP on the Basis of Current Prices for East Java Province in 2013-2017

\begin{tabular}{|c|c|c|c|c|c|c|}
\hline \multirow{2}{*}{ NO } & \multicolumn{6}{|c|}{ GRDP AT CURRENT PRICES IN EAST JAVA PROVINCE } \\
\hline & SECTOR & 2013 & 2014 & 2015 & 2016 & 2017 \\
\hline 1 & $\begin{array}{lll}\text { Agriculture, forestry } & \text { and } \\
\text { fisheries }\end{array}$ & 186038,31 & 208613,63 & 232282,81 & 246981,64 & 258428,10 \\
\hline 2 & Mining and excavation & 73777,25 & 78535,12 & 66526,21 & 69900,27 & 80846,20 \\
\hline 3 & Processing industry & 397997,72 & 445279,76 & 495699,68 & 536473,93 & 586258,60 \\
\hline 4 & $\begin{array}{l}\text { Procurement of electricity and } \\
\text { gas }\end{array}$ & 5168,15 & 5612,27 & 5948,48 & 6201,43 & 6675,20 \\
\hline 5 & $\begin{array}{l}\text { Water supply, waste and } \\
\text { recycling management }\end{array}$ & 1367,52 & 1434,53 & 1573,39 & 1735,84 & 1853,10 \\
\hline 6 & Construction & 127498,90 & 145884,63 & 160496,35 & 179816,56 & 197699,00 \\
\hline 7 & $\begin{array}{l}\text { Large trade and retail, car and } \\
\text { motorcycle repair }\end{array}$ & 244743,87 & 266734,05 & 297586,56 & 333996,36 & 367185,20 \\
\hline 8 & $\begin{array}{l}\text { Transportation } \\
\text { warehousing }\end{array}$ & 42435,22 & 50000,71 & 56741,54 & 63290,24 & 69176,40 \\
\hline 9 & $\begin{array}{l}\text { Provision of accommodation } \\
\text { and food drinks }\end{array}$ & 67904,45 & 79946,81 & 91476,26 & 104983,22 & 116058,30 \\
\hline 10 & $\begin{array}{l}\text { Information and } \\
\text { communication }\end{array}$ & 66085,76 & 69883,10 & 77087,45 & 85149,76 & 92928,70 \\
\hline 11 & $\begin{array}{l}\text { Financial and insurance } \\
\text { services }\end{array}$ & 36441,10 & 41204,81 & 46447,11 & 51655,34 & 55033,10 \\
\hline 12 & Real estate & 22540,31 & 24123,31 & 27560,77 & 29907,42 & 32080,20 \\
\hline 13 & Company services & 10904,70 & 12177,87 & 13538,46 & 14894,07 & 16255,90 \\
\hline
\end{tabular}




\begin{tabular}{|l|l|l|l|l|l|l|} 
& $\begin{array}{l}\text { Government administration, } \\
\text { defense and compulsory social } \\
\text { Security }\end{array}$ & 34694,83 & 35658,50 & 39137,39 & 43157,18 & 45740,70 \\
\hline 15 & Education services & 37680,74 & 41970,80 & 46006,23 & 49544,93 & 52974,10 \\
\hline & $\begin{array}{l}\text { Health services and social } \\
\text { activities }\end{array}$ & 8431,37 & 9682,65 & 10654,13 & 11527,46 & 12611,70 \\
\hline 17 & Other services & 18791,28 & 21205,10 & 24140,19 & 25827,05 & 27395,10 \\
\hline GRDP & 1382501,50 & 1537947,63 & 1692903,00 & 1855042,70 & 2019199,70 \\
\hline
\end{tabular}

Source: Central Bureau of Statistics In East Java Province 2013-2017

It can be seen that GRDP ADHB in East Java Province from 2013 up to 2017 increased with the sector that contributed the most, namely the manufacturing industry sector, while the sectors that contributed the least were the water supply, waste management, waste and recycling sectors. As a comparison, GRDP ADHB in East Java Province 2013 can be seen on the third table.

Table 3.

Surabaya City ADHB GRDP 2013-2017

\begin{tabular}{|c|c|c|c|c|c|c|}
\hline \multirow{2}{*}{ NO } & \multicolumn{6}{|c|}{ GRDP AT CURRENT PRICES SURABAYA } \\
\hline & SECTOR & 2013 & 2014 & 2015 & 2016 & 2017 \\
\hline 1 & $\begin{array}{l}\text { Agriculture, forestry and } \\
\text { fisheries }\end{array}$ & 607,88 & 671,44 & 746,57 & 808,81 & 883,18 \\
\hline 2 & Mining and excavation & 21,40 & 24,34 & 26,94 & 29,15 & 30,64 \\
\hline 3 & Processing industry & 62295,29 & 70956,47 & 78134,47 & 85214,74 & 92762,07 \\
\hline 4 & $\begin{array}{l}\text { Procurement of electricity and } \\
\text { gas }\end{array}$ & 1951,12 & 2001,21 & 2093,85 & 2144,72 & 2263,68 \\
\hline 5 & $\begin{array}{l}\text { Water supply, waste and } \\
\text { recycling management }\end{array}$ & 543,49 & 572,05 & 626,53 & 678,59 & 740,17 \\
\hline 6 & Construction & 33623,37 & 37876,19 & 40626,35 & 45103,25 & 49603,61 \\
\hline 7 & $\begin{array}{l}\text { Large trade and retail, car and } \\
\text { motorcycle repair }\end{array}$ & 92633,74 & 99966,84 & 111677,56 & 124579,58 & 137322,73 \\
\hline 8 & $\begin{array}{ll}\text { Transportation } & \text { and } \\
\text { warehousing } & \end{array}$ & 16243,53 & 19016,38 & 21370,86 & 23617,51 & 26215,30 \\
\hline 9 & $\begin{array}{l}\text { Provision of accommodation } \\
\text { and food drinks }\end{array}$ & 46517,65 & 54062,91 & 61613,86 & 70854,86 & 78971,93 \\
\hline 10 & $\begin{array}{l}\text { Information } \\
\text { communication }\end{array}$ & 19038,48 & 20137,83 & 22165,99 & 24457,11 & 26571,78 \\
\hline 11 & Financial and insurance services & 16897,67 & 19275,91 & 21640,84 & 24105,84 & 25631,47 \\
\hline 12 & Real estate & 8747,17 & 9372,18 & 10706,03 & 11539,14 & 12495,06 \\
\hline 13 & Company services & 8072,65 & 8889,03 & 9852,48 & 10926,17 & 12098,85 \\
\hline 14 & $\begin{array}{l}\text { Government administration, } \\
\text { defense and compulsory social } \\
\text { security }\end{array}$ & 4966,81 & 5071,61 & 5602,25 & 6221,29 & 6768,29 \\
\hline 15 & Education services & 8329,24 & 9259,95 & 10156,32 & 11036,18 & 11958,10 \\
\hline 16 & $\begin{array}{l}\text { Health services and social } \\
\text { activities }\end{array}$ & 2472,71 & 2814,32 & 3089,80 & 3389,78 & 3730,51 \\
\hline
\end{tabular}




\begin{tabular}{|l|l|l|l|l|l|l|}
17 & Other services & 4839,85 & 5382,30 & 6092,80 & 6676,54 & 6995,94 \\
\hline GRDP & & & & & \\
& 327802,05 & 365350,96 & 406223,50 & 451383,26 & 495043,31 \\
\hline
\end{tabular}

Source: Surabaya City Statistics Agency 2013-2017

Surabaya City ADHB GRDP has increased from 2013 to 2017. The sectors that have the largest contribution are the large and retail trade sectors; car and motorcycle repairing, while the least contribution is mining. Analysis calculation of local economic potential and economic competitiveness in Surabaya city uses a comparison of the GRDP data of the ADHB with a comparison of the same year. In the fourth table is a result calculation of the economic potential of Surabaya City in 2013-2017 using Location Quotient analysis.

Table 4.

Results of Surabaya Local Economic Potential Calculation 2013-2017

\begin{tabular}{|c|c|c|c|c|c|c|c|c|}
\hline \multirow{2}{*}{ NO } & \multicolumn{6}{|c|}{ LOCATION QUOTIENT SURABAYA } & \multirow[t]{2}{*}{ AVERAGE } & \multirow[t]{2}{*}{ RANK } \\
\hline & SECTOR & 2013 & 2014 & 2015 & 2016 & 2017 & & \\
\hline 1 & $\begin{array}{l}\text { Agriculture, forestry and } \\
\text { fisheries }\end{array}$ & 0,014 & 0,014 & 0,013 & 0,013 & 0,014 & 0,014 & 16 \\
\hline 2 & Mining and excavation & 0,001 & 0,001 & 0,002 & 0,002 & 0,002 & 0,001 & 17 \\
\hline 3 & Processing industry & 0,660 & 0,671 & 0,657 & 0,653 & 0,645 & 0,657 & 14 \\
\hline 4 & $\begin{array}{l}\text { Procurement of electricity } \\
\text { and gas }\end{array}$ & 1,592 & 1,501 & 1,467 & 1,421 & 1,383 & 1,473 & 8 \\
\hline 5 & $\begin{array}{l}\text { Water supply, waste and } \\
\text { recycling management }\end{array}$ & 1,676 & 1,679 & 1,659 & 1,607 & 1,629 & 1,650 & 4 \\
\hline 6 & Construction & 1,112 & 1,093 & 1,055 & 1,031 & 1,023 & 1,063 & 11 \\
\hline 7 & $\begin{array}{l}\text { Large trade and retail, car } \\
\text { and motorcycle repair }\end{array}$ & 1,596 & 1,578 & 1,564 & 1,533 & 1,525 & 1,559 & 7 \\
\hline 8 & $\begin{array}{l}\text { Transportation } \quad \text { and } \\
\text { warehousing }\end{array}$ & 1,614 & 1,601 & 1,570 & 1,534 & 1,546 & 1,573 & 6 \\
\hline 9 & $\begin{array}{l}\text { Provision } \\
\text { accommodation and food } \\
\text { drinks }\end{array}$ & 2,889 & 2,847 & 2,807 & 2,774 & 2,775 & 2,818 & 2 \\
\hline 10 & $\begin{array}{l}\text { Information } \\
\text { communication }\end{array}$ & 1,215 & 1,213 & 1,198 & 1,180 & 1,166 & 1,195 & 10 \\
\hline 11 & $\begin{array}{l}\text { Financial and insurance } \\
\text { services }\end{array}$ & 1,956 & 1,969 & 1,942 & 1,918 & 1,900 & 1,937 & 3 \\
\hline 12 & Real estate & 1,637 & 1,635 & 1,619 & 1,586 & 1,589 & 1,613 & 5 \\
\hline 13 & Company services & 3,122 & 3,073 & 3,033 & 3,015 & 3,036 & 3,056 & 1 \\
\hline 14 & $\begin{array}{l}\text { Government } \\
\text { administration, defense and } \\
\text { compulsory social security }\end{array}$ & 0,604 & 0,599 & 0,597 & 0,592 & 0,604 & 0,599 & 15 \\
\hline 15 & Education services & 0,932 & 0,929 & 0,920 & 0,915 & 0,921 & 0,923 & 13 \\
\hline 16 & Health services and social & 1,237 & 1,224 & 1,209 & 1,208 & 1,207 & 1,217 & 9 \\
\hline
\end{tabular}




\begin{tabular}{|l|l|l|l|l|l|l|l|l|} 
& activities & & & & & & & \\
\hline 17 & Other services & 1,086 & 1,068 & 1,052 & 1,062 & 1,042 & 1,062 & 12 \\
\hline
\end{tabular}

Source: processed author

On the fourth table, it can be seen that every year from 2013 up to 2017, the economic sector has the same potential every year. Sectors that are potentially in accordance with the order of potential from the most potential to the least potential are as follows: a) company services sector; b) provision of accommodation and food drinks sectors; c) financial and insurance services sector; d) water supply, waste and recycling management sector; e) real estate sector; f) transportation and warehousing sector; g) large trade and retail, car and motorcycle repair sectors; h) procurement of electricity and gas; i) health services and social activities sector; $j$ ) information and communication sector; $k$ ) construction sector; 1 ) other services sector; $\mathrm{m}$ ) education services sector; $\mathrm{n}$ ) processing industry sector; o) government administration, defense and compulsory social security sector; p) agriculture, forestry and fisheries sectors; and q) mining and excavation sector.

The average results of the analysis of the local economic potential of Surabaya City in 2013-2017 and the average for 5 years along with the order of the most potential sectors up to the least potential sector. The average results of economic potential during 2013-2017 from the greatest potential to the small potential are as follows:
a. Company services sector $=3.056$
b. Provision of accommodation and eating drinks sector $=2.818$
c. Financial and insurance services sector $=1,937$
d. Water supply, waste and recycling management sector $=1,650$
e. Real estate sector $=1,613$
f. Transportation and warehousing sector $=1,573$
g. Large trade and retail, car and motorcycle repair sector $=1,559$
h. Procurement of electricity and gas sector $=1,473$
i. Health services and social activities sector $=1,217$
j. Information and communication sector $=1,195$
k. Construction sector $=1,063$
1. Other services sector $=1.062$ 
The average results of the sector that are not potential during 2013-2017 from the largest to the small are as follows:
a. Education sector $=0.923$
b. Processing industry sector $=0.657$
c. Government administration, defense and compulsory social security sector $=0.599$
d. Agriculture, forestry and fishery sector $=0.014$
e. Mining and excavation sector $=0.001$

Potential sectors that have been mapped with this method can be used by the Surabaya city government as a basis for policy making. The policy making will be more focused on developing potential sectors which ultimately will act as a sector capable of acting as a trigger for development. The development planning process that will be made is also necessary to consider the existing conditions of the city of Surabaya. These conditions are related to demographics, mapping of existing areas, potential stakeholders, and consideration of other important conditions. Development that has been focused on potential sectors and taking into account the condition of the city of Surabaya, will be able to encourage potential sectors which will eventually become a sector lever for the another sectors.

Non-superior sectors also needs to get attention in development. This concern is not in the focus of the policy that will be made, but the policies made will not deviate far into the development of the non-superior sector. An example that can be used is the city government of Surabaya which does not need to focus on development in the mining and quarrying sector, this is because in addition the sector is not too developed in Surabaya, also the need for land is quite extensive in implementing this sector. In addition, if the Surabaya city government wants to develop the mining and quarrying sector, it will face increasingly severe environmental problems, because the city of Surabaya itself is currently preoccupied with environmental issues as one of the metropolitan cities in Indonesia.

Table 5.

Results of Calculation of Surabaya's Local Economic Competitiveness in 2013-2017

\begin{tabular}{|c|c|c|c|c|c|c|}
\hline \multirow[t]{2}{*}{ NO } & \multirow[t]{2}{*}{ SECTOR } & \multicolumn{3}{|c|}{ SHIFT SHARE } & \multirow[b]{2}{*}{$\begin{array}{l}\text { SHIFT } \\
\text { SHARE }\end{array}$} & \multirow[b]{2}{*}{ RANK } \\
\hline & & $\begin{array}{l}\text { NATIONAL } \\
\text { SHARE }\end{array}$ & $\begin{array}{l}\text { INDUSTRIAL } \\
\text { MIX }\end{array}$ & $\begin{array}{l}\text { COMPETITIVE } \\
\text { POSITION }\end{array}$ & & \\
\hline 1 & $\begin{array}{l}\text { Agriculture, forestry } \\
\text { and fisheries }\end{array}$ & 12478,15746 & $-12419,48908$ & 10,1566241 & 68,83 & 15 \\
\hline 2 & $\begin{array}{l}\text { Mining and } \\
\text { excavation }\end{array}$ & 448,2224173 & $-447,3251036$ & 1,412686347 & 2,31 & 17 \\
\hline 3 & Processing industry & 1305528,567 & $-1298086,031$ & 174,1586225 & 7616,69 & 3 \\
\hline 4 & $\begin{array}{l}\text { Procurement of } \\
\text { electricity and gas }\end{array}$ & 36075,19007 & $-35940,07999$ & $-56,97007583$ & 78,14 & 14 \\
\hline 5 & Water supply, waste & 10657,4568 & $-10609,3234$ & 1,036600767 & 49,17 & 16 \\
\hline
\end{tabular}




\begin{tabular}{|c|c|c|c|c|c|c|}
\hline & $\begin{array}{l}\text { and recycling } \\
\text { management }\end{array}$ & & & & & \\
\hline 6 & Construction & 692107,7197 & $-687603,1692$ & $-509,4905501$ & 3995,06 & 4 \\
\hline 7 & $\begin{array}{l}\text { Large trade and } \\
\text { retail, car and } \\
\text { motorcycle repair }\end{array}$ & 1887741,044 & $-1876258,753$ & $-310,0439747$ & 11172,25 & 1 \\
\hline 8 & $\begin{array}{l}\text { Transportation and } \\
\text { warehousing }\end{array}$ & 353164,1719 & $-350633,5222$ & $-37,70720214$ & 2492,94 & 5 \\
\hline 9 & $\begin{array}{l}\text { Provision of } \\
\text { accommodation and } \\
\text { food drinks }\end{array}$ & 1025488,719 & $-1017334,078$ & $-41,0703797$ & 8113,57 & 2 \\
\hline 10 & $\begin{array}{l}\text { Information and } \\
\text { communication }\end{array}$ & 377719,8182 & $-375789,1753$ & $-47,31794554$ & 1883,33 & 7 \\
\hline 11 & $\begin{array}{l}\text { Financial and } \\
\text { insurance services }\end{array}$ & 360539,4934 & $-358373,4335$ & 17,39007256 & 2183,45 & 6 \\
\hline 12 & Real estate & 177683,7457 & $-176758,8245$ & 12,0512845 & 936,97 & 9 \\
\hline 13 & Company services & 166122,8604 & $-165142,5566$ & 26,24623793 & 1006,55 & 8 \\
\hline 14 & $\begin{array}{l}\text { Government } \\
\text { administration, } \\
\text { defense and } \\
\text { compulsory social } \\
\text { security }\end{array}$ & 96250,64723 & $-95855,50226$ & 55,22502587 & 450,37 & 12 \\
\hline 15 & Education services & 170717,294 & $-169871,3711$ & 61,29217373 & 907,22 & 10 \\
\hline 16 & $\begin{array}{l}\text { Health services and } \\
\text { social activities }\end{array}$ & 51792,04902 & $-51486,68834$ & 9,089320764 & 314,45 & 13 \\
\hline 17 & Other services & 101196,4792 & $-100647,0308$ & $-10,42586168$ & 539,02 & 11 \\
\hline
\end{tabular}

Source: processed by researchers

National economic growth (national growth effect) or can be called a national share is used to see how the influence of national economic growth on the region. Proportional shift is used to measure the relative (up / down) changes in a regional sector to the same sector at the national level, this component is also called the industry mix effect. Differential shift is used to find out how competitive a particular sector of a region is compared to the national, this component is also called the influence of competitive advantage. Shift share as an analysis consisting of the sum of the components of the national share, industrial mix and competitive position. It can be seen from the fifth table that the most competitive economic sectors are large trade and retail, car and motorcycle repair; provision of accommodation and eating drinks; processing industry; and Construction. But on the other hand, a sector that lacks competitiveness is not a sector that is not feasible to develop, but needs to be encouraged with the right policies by the government as a party that is obliged to plan and carry out development. Examples of the Health services and social activities sector, although occupying a position that is not competitive, also need to be developed and received more 
attention, because the city of Surabaya is a city that has a function as a health service center at the provincial level.

The results of LQ and SS calculations will not provide an up-to-date description of the position of the development sector. Comparison between calculations to determine regional potential and regional competitiveness have at least spawned several sectors that are potential and feasible to be developed and compared to other regions.

The Provision of accommodation and food drinks sector is a potential sector or a superior sector that has high competitiveness compared to other regions. This sector is the most promising sector, because from each calculation result it takes in the second place. Policies to develop this sector can be focused by providing facilitation for stakeholders, because looking at the conditions in this sector already has a good environment. In addition, there are 2 other sectors that are also feasible to serve as a leading sector with good competitiveness, namely the transportation and warehousing sector; and Financial and insurance services. Both of them illustrate that Surabaya city is a city that deserves to be the center of mobility in the eastern part of Indonesia by developing a variety of more advanced and futuristic modes of transportation. Surabaya also needs to be a center for financial and insurance services, because this sector is a fairly superior sector with various service companies which moved in financial services in various sectors.

The position of the comparison results show that there is a sector that is superior or regional potential but does not have competitiveness. The sector of Water supply, waste and recycling management becomes the first sector in this position, the government's role in this sector is still too prominent, because the conditions in Surabaya shows that the role of the private sector and the public are still minimal. An example is the processing of waste which is still the responsibility of the government, while water treatment is also occupied by BUMD which also indirectly is the government too. So that in this sector indirectly needs to be decentralization of affairs to the public or the private sector. The Real estate sector is also superior and can be considered low competitiveness, because this is related to housing and office supply. So that it can be considered quite difficult to be competitive. The leading sector with the last low competitiveness is Company services. This sector has a vital role in development in Surabaya, because it proved to be the first rank as a leading sector, but after shiftshare has done, this sector has low competitiveness. Further reasons need to be known 
in an effort to determine the direction of policy that will encourage the role of this sector to become a competitive sector.

In the last sector category is a sector that is not potential or superior regions, but this is sector has high competitiveness positions. Processing industry sector is become a sector with high competitiveness, even though this sector is not a regional potential and also not superior which is owned by the city of Surabaya. Looking at the conditions in Surabaya city, this sector is only concentrated in a number of small areas in the suburbs. The role of this region is labor intensive, so that if the city government will develop this sector, it is necessary to make policies that will definitely relate to the capacity of the Surabaya city itself. The Large trade and retail sector, car and motorcycle repair are other sectors that lack potential, but this sector has the highest competitiveness. The reason for this condition is the role of the Surabaya city as an economic center in eastern Indonesia which indirectly will be able to encourage the development process of Surabaya city. The low level of superior development potential in the sector needs to be studied more by the city of Surabaya, so that in the future the government that wants to make this sector as the main sector in regional development can create policies that will encourage this sector to become the main sector in regional development.

The last sector category is a sector that is not a leading sector and a sector that has low competitiveness. The sectors included in this category are Agriculture, forestry and fisheries; and Mining and excavation. Both sectors have a role that has a significant development low. However, with this analysis, it is indirectly provides firmness to the Surabaya city government not to give more attention to the sector. The government only needs to carry out supervision in this sector so that it does not have an adverse impact on the community.

\section{Conclusion}

The Provision of accommodation and food drinks sector is a potential sector or a superior sector that has high competitiveness compared to other regions. This sector is the most promising sector, because from each calculation result it takes in the second place. Policies to develop this sector can be focused by providing facilitation for stakeholders, because looking at the conditions in this sector already has a good environment. In addition, 
there are 2 other sectors that are also feasible to serve as a leading sector with good competitiveness, namely the transportation and warehousing sector; and Financial and insurance services. Both of them illustrate that Surabaya city is a city that deserves to be the center of mobility in the eastern part of Indonesia by developing a variety of more advanced and futuristic modes of transportation.

In the end, the Surabaya city government wants to do development quickly, only needs to focus on the first category sectors that have high potential and competitiveness. Treatment in this sector is not too difficult, because the Surabaya city government only needs to oversee the implementation of policies relating to this sector only and stakeholders in this sector will automatically work effectively.

\section{References}

Abipraja, Soedjono. 2002. Development Planning in Indonesia (Concepts, Models, Policies, Instruments and Strategies). Surabaya: Airlangga University Press Adisasmita, Raharjo. 2013. Theories of Economic Development (Economic Growth and Regional Growth). Yogyakarta: Graha Ilmu.

Adisasmita, Raharjo. 2008. Economy of Archipelago. Yogyakarta: Graha Ilmu.

Adisasmita, Raharjo. 2008. Regional Development: Concepts and Theories. Yogyakarta: Graha Ilmu.

Arsyad, Lincolin. 2010. Development Economics. Yogyakarta: STIM YKPN Publishing and Printing Unit.

Blakely and Bradshaw. 2002. Planning Local Economic Development: Theory and Practice

Central Java Provincial Statistics Agency. 2015. "East Java Gross Domestic Product". Accessed on September 24, 2015 at www.jatim.bps.go.id.

Bratakusumah, Riyadi Deddy Supriady. 2004. Regional Development Planning (Strategy to Explore Potentials in Realizing Regional Autonomy). Jakarta: PT Gramedia Pustaka Umum.

Cresswell, John W. 2014. Research Design Qualitative, Quantitative and Mixed Approaches. Translated by Achmad Fawaid. Yogyakarta: Pustaka Pelajar.

Darmawan, Deni. 2014. Quantitative Research Methods. Bandung: PT Remaja Rosdakarya. 
Hafizrianda, Yundy, and Arief Daryanto. 2010. Quantitative Models for Regional Economic Development Planning (Concepts and Applications). Bogor: PT Publisher IPB Press.

Ministry of National Development Planning, t.t. Attachment of Presidential Regulation Number 2 of 2015 concerning the 2015-2019 National Medium Term Development Plan. Jakarta.

East Java Provincial Government, t.t. Preliminary Design of RPJMD of East Java Province for 2014-2019. Surabaya.

Putra, Fadillah. 2011. Study of Public Policy and Government in Quantitative Perspectives (Techniques, Methods and Approaches). Malang: Universitas Brawijaya Press.

Sjafrizal. 2008. Regional Economics (Theory and Application). Padang: Pranita Offset.

Sjafrizal. 2009. Practical Techniques for Preparing Regional Development Plans. Padang: Baduose Media.

Soleh, Chabib. 2014. Dialectics of Development with Empowerment. Bandung: FOCUSMEDIA. Taringan, Robinson. 2005. Regional Development Planning. Jakarta: PT. Bumi Aksara. 